\title{
PENINGKATAN KEMAMPUAN PENYUSUNAN RENCANA PELAKSANAAN PEMBELAJARAN GURU MIN AMKOTENG MELALUI SUPERVISI AKADEMIK
}

Berkati

Kantor Kementrian Agama Kabupaten Barito Kuala

E-mail: berkatipengawas@gmail.com

\begin{abstract}
The purpose of this study was to determine the increase in the ability of teachers in preparing Learning Implementation Plans (RPP) through academic supervision. This research is a school action research with steps: planning, implementation, observation, and reflection. This research is planned to consist of two cycles. This research was carried out at MIN Amkoteng Subdistrict Anjir Muara, Barito Kuala District, South Kalimantan Province. Quantitative data analysis was used to determine the increase in the value of the practice of making RPP by teachers based on the standards set by the Ministry of National Education. The results of the study show that the teacher's ability to prepare RPP can be improved by academic supervision; collaboration between teachers and Supervisors of Primary Schools can be well established and useful in fostering teachers to improve their abilities in preparing RPP; the complete document II of the Education Unit (KTSP) MIN Amkoteng curriculum is complete, in the form of RPP collection documents; and this academic supervision can be used as a model in the following years in terms of drafting RPP, and can be used as an example for other schools.
\end{abstract}

Key Words: ability; lesson plan; academic supervision

\section{ABSTRAK}

Tujuan penelitian ini untuk mengetahui peningkatan kemampuan guru dalam menyusun Rencana Pelaksanaan Pembelajaran (RPP) melalui supervisi akademik. Penelitian ini merupakan penelitian tindakan sekolah dengan langkah-langkah: perencanan, pelaksanaan, pengamatan, dan refleksi. Penelitian ini direncanakan terdiri dari dua siklus. Penelitian ini dilaksanakan di MIN Amkoteng Kecamatan Anjir Muara Kabupaten Barito Kuala Provinsi Kalimantan Selatan. Analisis data kuantitatif digunakan untuk mengetahui peningkatan nilai praktik pembuatan RPP oleh guru berdasarkan standar yang telah ditetapkan Depdiknas. Hasil penelitian menunjukkan bahwa kemampuan guru dalam menyusun RPP dapat ditingkatkan dengan supervisi akademik; kerjasama antara guru dan Pengawas Sekolah Dasar dapat terjalin dengan baik dan bermanfaat dalam membina guru untuk meningkatkan kemampuannya dalam penyusunan RPP; kelengkapan dokumen II Kurikulum Tingkat Satuan Pendidikan (KTSP) MIN Amkoteng bertambah lengkap, yaitu berupa dokumen kumpulan RPP; dan supervisi akademik ini dapat dijadikan model pada tahun-tahun berikutnya dalam hal penyusunan RPP, dan dapat dijadikan contoh bagi sekolah lain.

Kata Kunci: kemampuan; rencana pelaksanaan pembelajaran; supervisi akademik

\section{PENDAHULUAN}

Kompetensi supervisi akademik intinya adalah membina guru dalam meningkatkan mutu proses pembelajaran. Sasaran supervisi akademik adalah guru dalam melaksanakan proses pembelajaran, yang terdiri dari materi pokok dalam proses pembelajaran, penyusunan silabus dan RPP, pemilihan strategi/metode/teknik pembelajaran, penggunaan media dan teknologi informasi dalam pembelajaran, menilai proses dan hasil pembelajaran serta penelitian tindakan kelas (Kemdiknas, 2010b : 6). Pentingnya pelaksanaan supervisi akademik untuk meningkatkan kemampuan profesional guru dan meningkatkan kualitas pembelajaran melalui proses pembelajaran yang baik serta membantu guru dan Pengawas Sekolah Dasar menciptakan lulusan yang baik dari segi kualitas maupun kuantitas. Oleh karena itu, kegiatan supervisi ini 
hendaknya rutin dilaksanakan di sekolah sebagai salah satu kegiatan yang dipandang positif dalam meningkatkan proses pembelajaran. Apabila konsep-konsep ideal tersebut dilaksanakan, maka dapat diharapkan kualitas pendidikan akan meningkat secara signifikan (Ali Rifan dalam rifqiemaulana.wordpress.com).

Kenyataan yang ditemukan di MIN Amkoteng bahwa ada permasalahan bagi guru dalam menyusun Rencana Pelaksanaan Pembelajaran (RPP), pada umumnya guru hanya menyadur kepunyaan orang lain, hanya sebagian kecil guru yang membuat RPP sendiri. Permasalahan ini besar kemungkinan disebabkan oleh:

1. Tidak semua guru mampu menyusun perencanaan RPP dengan baik

2. Sebagian besar RPP yang ada pada guru adalah hasil meniru RPP dari buku-buku, rekan guru yang lain, maupun dari sumber-sumber yang lain

3. RPP yang dibuat oleh guru mempunyai kekurangan sebagai berikut:

a. Indikator dan tujuan pembelajaran yang dirumuskan oleh guru masih menggunakan kata kerja tidak operasional

b. Belum dilengkapi dengan instrument penilaian, kebanyakan hanya mencantumkan contoh instrumennya saja

c. Penilaian hasil belajar siswa dalam RPP belum dilengkapi teknik penskoran.

4. Kurang meratanya sosialisasi (Diklat) mengenai penyusunan PPP dan dari Kemenag Barito Kuala.

5. MIN Amkoteng belum melaksanakan bimbingan khusus kepada guru-guru dalam menyusun RPP.

Meskipun demikian, supervisi akademik tidak bisa terlepas dari penilaian unjuk kerja guru dalam mengelola pembelajaran. Apabila di atas dikatakan, bahwa supervisi akademik merupakan serangkaian kegiatan membantu guru mengembangkan kemampuannya mengelola proses pembelajaran, maka menilai unjuk kerja guru dalam mengelola proses pembelajaran merupakan salah satu kegiatan yang tidak bisa dihindarkan prosesnya. Menurut Depdiknas (2007a : 162) dalam Buku Materi Sosialisasi dan pelatihan Kurikulum Tingkat Satuan Pendidikan (KTSP) dijelaskan Rencana Pelaksana Pembelajaran (RPP) adalah rencana yang menggambarkan prosedur dan pengorganisasian pembelajaran untuk mencapai suatu kompetensi dasar yang ditetapkan dalam Standar isi dan telah dijabarkan dalam silabus, Lingkup Rencana Pembelajaran paling luas mencakup 1 (satu) kompetensi dasar yang terdiri dari 1 (satu) atau beberapa indikator untuk 1 (satu) kali pertemuan atau lebih.

Depdiknas (2007b : 2) menuliskan Peraturan Pemerintah No. 19 tahun 2005 Pasal 20 yang menjelaskan bahwa perencanaan proses pembelajaran meliputi silabus dan rencana pelaksanaan pembelajaran yang memuat sekurang-kurangnya tujuan pembelajaran, materi pembelajaran, metode pembelajaran, sumber belajar, dan penilaian hasil belajar. Menurut Sullivan Glanz (2005) sebagaimana ditulis oleh Kemdiknas (2010b: 34), ada empat langkah supervisi akademik klinis, yaitu:

1. Perencanaan pertemuan

2. Observasi

3. Pertemuan berikutnya, dan

4. Refleksi kolaborasi.

Berdasarkan uraian tersebut, maka perlu dilakukan penelitian untuk mengetahui peningkatan kemampuan guru dalam menyusun Rencana Pelaksanaan Pembelajaran (RPP) melalui supervisi akademik.

\section{METODE PENELITIAN}


Penelitian ini merupakan penelitian tindakan sekolah dengan langkah-langkah: perencanan, pelaksanaan, pengamatan, dan refleksi. Penelitian ini direncanakan terdiri dari dua siklus. Langkah-langkah PTS tersebut dapat digambarkan sebagai berikut:

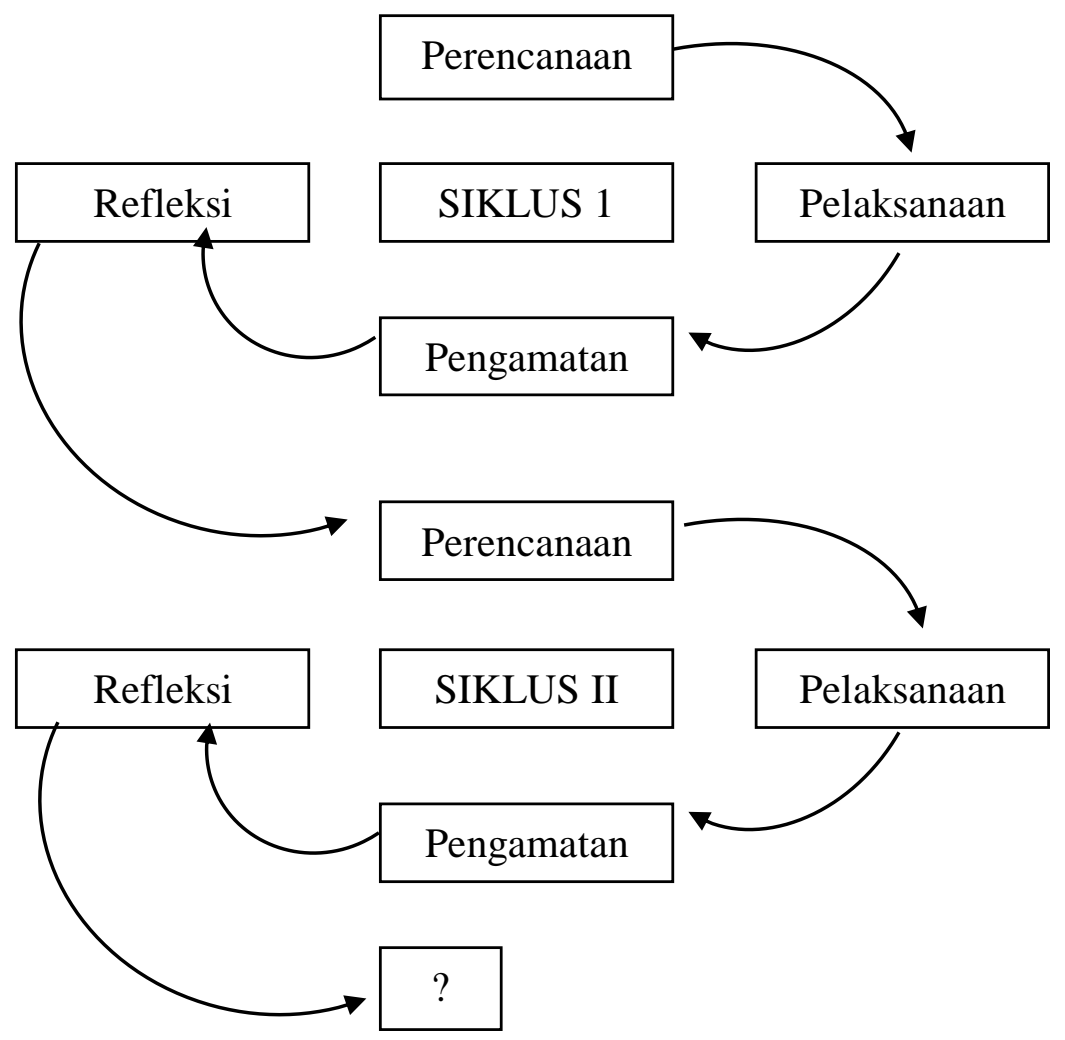

Gambar 1. Langkah-langkah PTS (Kemdiknas 2010a : 12)

Penelitian ini dilaksanakan di MIN Amkoteng Kecamatan Anjir Muara Kabupaten Barito Kuala Provinsi Kalimantan Selatan. Guru yang diteliti di sekolah ini berjumlah 10 orang, guru kelas I sampai VI keseluruhannya berstatus Pegawai Negeri Sipil (PNS) dan Non PNS. Pelaksanaan penelitian tindakan sekolah selama 6 bulan, bulan Juli, Agustus, September, Oktober dan November, Desember. Faktor yang akan diselidiki dalam penelitian ini adalah teknis/kemampuan guru dalam menyusun/membuat RPP. Kemdiknas (2010b: 34) merincikan langkah-langkah supervisi akademik klinis sebagai berikut:

1. Perencanaan pertemuan, meliputi:

a. Memutuskan fokus observasi (pendekatan umum, informasi langsung, kolaboratif, atau langsung diri sendiri)

b. Menetapkan metode dan formulir observasi

c. Mengatur observasi dan pertemuan berikutnya.

2. Langkah-langkah observasi:

a. Memilih alat observasi

b. Melaksanakan observasi

c. Memverifikasi hasil observasi dengan guru pada pertemuan berikutnya

d. Menganalisis data hasil verifikasi dan menginterpretasi

e. Memilih pendekatan interpersonal setelah pertemuan berikutnya.

3. Langkah-langkah pertemuan berikutnya adalah menentukan fokus dan waktu

4. Langkah-langkah refleksi kolaborasi:

a. Menemukan nilai-nilai

b. Menentukan yang kurang bernilai 
c. Menentukan saran-saran yang bisa diajukan

Analisis data kuantitatif digunakan untuk mengetahui peningkatan nilai praktik pembuatan RPP oleh guru berdasarkan standar yang telah ditetapkan Depdiknas seperti dikutip Zainal Aqib (2009 : 48) sebagai berikut:

a. Nilai $91-100=$ amat baik (A), berhasil

b. Nilai $76-90=$ baik $(B)$, berhasil

c. Nilai $55-75=$ cukup $(\mathrm{C})$, belum berhasil

d. Nilai $0-54=$ kurang $(\mathrm{D})$, belum berhasil

$\begin{aligned} \text { Nilai akhir } & =\frac{\text { SkorTotal } \times 100}{\text { Skor Maksimal }} \\ & =\frac{\ldots \ldots \ldots \ldots \ldots . \ldots 100}{100}\end{aligned}$

Keseluruhan data yang terkumpul selanjutnya dipergunakan untuk menilai keberhasilan tindakan dengan indikator keberhasilan berupa peningkatan nilai lembar observasi Rencana Pelaksanaan Pembelajaran (RPP) pada dua siklus yang dilaksanakan. Adapun nilai indikator keberhasilan dalam lembar observasi Rencana Pelaksanaan Pembelajaran (RPP) berkisar antara $91-100$.

\section{HASIL PENELITIAN DAN PEMBAHASAN}

\section{A. Hasil Penelitian}

Selama proses pelaksanaan Penelitian Tindakan Madrasah dilaksanakan dengan menggunakan dua siklus. Berikut hasil dari penelitian siklus satu:

Tabel 1. Data Hasil Pelaksanaan Tindakan Siklus I

\begin{tabular}{|c|c|c|c|c|}
\hline \multirow[b]{2}{*}{ No. } & \multirow{2}{*}{ Rentang Nilai } & \multicolumn{2}{|c|}{ Hasil Penilaian RPP } & \multirow{2}{*}{$\begin{array}{c}\text { Kriteria } \\
\text { Keberhasilan }\end{array}$} \\
\hline & & Frekuensi & $\%$ & \\
\hline 1. & $91-100$ & - & - & A \\
\hline 2. & $76-90$ & 8 & 80 & B \\
\hline 3. & $55-75$ & 2 & 20 & $\mathrm{C}$ \\
\hline 4. & $0-54$ & 0 & - & $\mathrm{D}$ \\
\hline & Jumlah & 10 & 20 & \\
\hline
\end{tabular}

Data tabel 1 tersebut dapat digambarkan dengan grafik berikut :

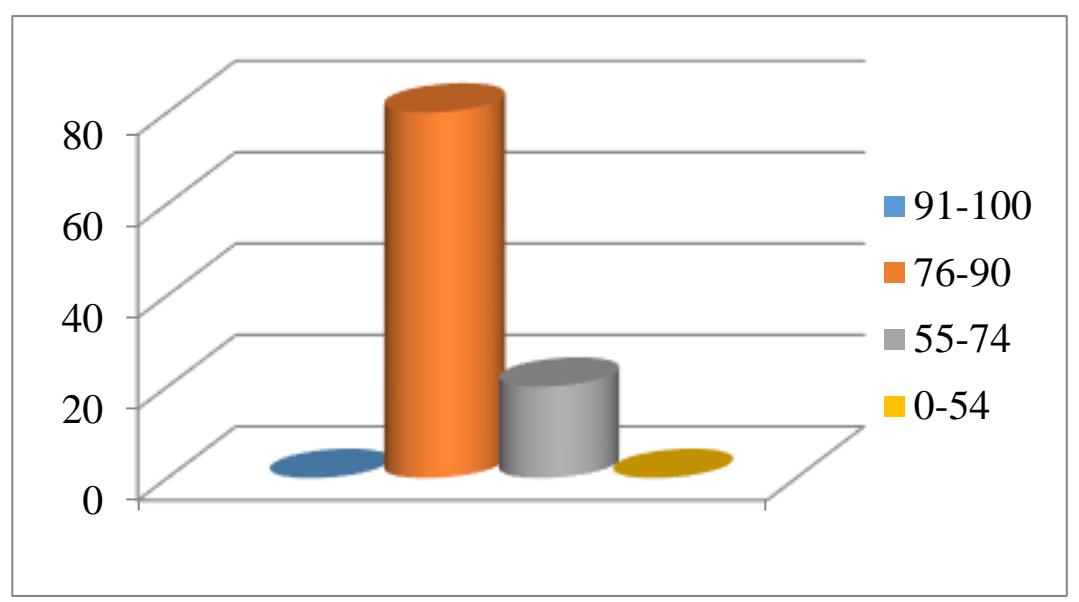

Gambar 2. Persentase Pencapaian Rentang Nilai Keberhasilan Guru dalam Penyusunan RPP pada Siklus I 
Berdasarkan data hasil pelaksanaan tindakan siklus 1 di atas, dapat diambil refleksi bahwa $80 \%$ guru MIN Amkoteng sudah dapat membuat RPP dengan baik, kriteria baik disini berarti penyusunan RPP guru yang bersangkutan telah mencapai rentang nilai $76-90$.

Sedangkan $20 \%$ lagi belum berhasil mencapai kriteria keberhasilan, artinya penyusunan RPP yang bersangkutan belum mencapai rentang nilai $76-90$.

Dengan data yang didapat seperti diuraikan di atas, tentu diperlukan tindakan siklus II untuk meningkatkan kemampuan guru dalam menyusun RPP, sehingga diharapkan $100 \%$ guru MIN Amkoteng(10 orang) dapat mencapai rentang nilai minimal 76 - 90. Lebih bagus lagi apabila ada guru yang mampu memperoleh rentang nilai 91 - 100 pada pembuatan RPP.

Berikut juga dipaparkan hasil pelaksanaan siklus dua sebagai berikut:

Tabel 2. Data Hasil Pelaksanaan Tindakan Siklus II

\begin{tabular}{|c|c|c|c|c|}
\hline \multirow{2}{*}{ No. } & \multirow{2}{*}{ Rentang Nilai } & \multicolumn{2}{|c|}{ Hasil Penilaian RPP } & \multirow{2}{*}{$\begin{array}{c}\text { Kriteria } \\
\text { Keberhasilan }\end{array}$} \\
\hline & & Frekuensi & $\%$ & \\
\hline 1. & $91-100$ & 4 & 40 & $\mathrm{~A}$ \\
\hline 2. & $76-90$ & 6 & 60 & B \\
\hline 3. & $55-75$ & - & - & $\mathrm{C}$ \\
\hline 4. & $0-54$ & - & - & $\mathrm{D}$ \\
\hline & Jumlah & 10 & 100 & \\
\hline
\end{tabular}

Data tabel 2 tersebut dapat digambarkan dengan grafik berikut :

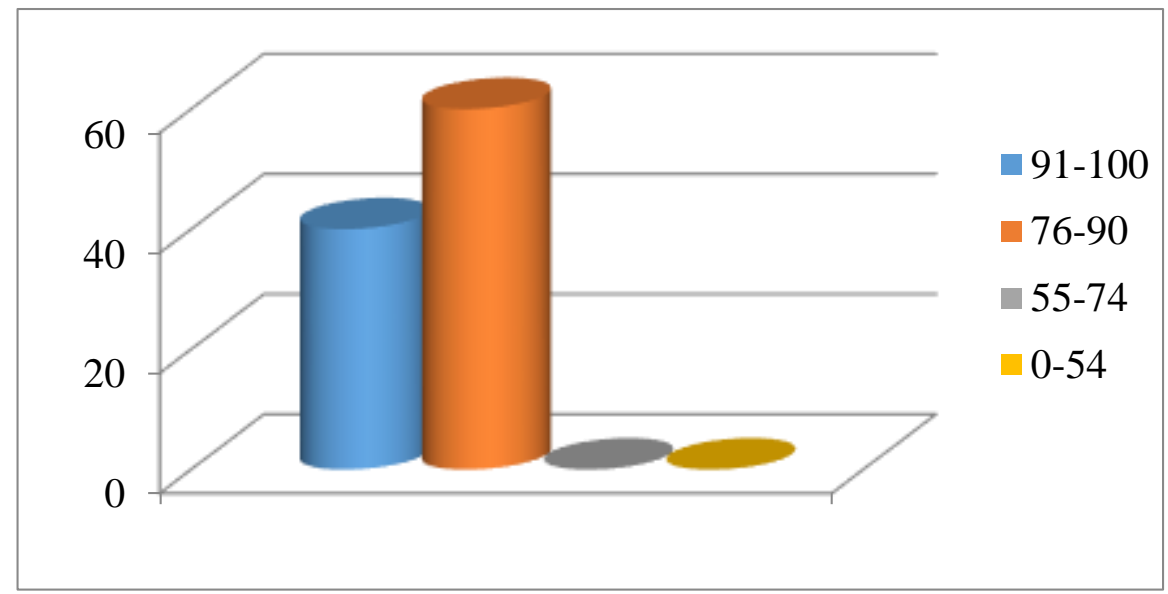

Gambar 3. Persentase Pencapaian Rentang Nilai Keberhasilan Guru dalam Penyusunan RPP pada Siklus II

Berdasarkan data hasil pelaksanaan tindakan siklus II di atas, dapat diambil refleksi bahwa 100\% guru MIN Amkoteng sudah dapat membuat RPP dengan baik, kriteria baik disini berarti penyusunan RPP guru yang bersangkutan telah mencapai rentang nilai 76 - 90, bahkan $40 \%$ diantaranya telah mampu mencapai rentang nilai 91 - 100. Dengan data yang didapat seperti diuraikan di atas, tindakan siklus II telah mampu meningkatkan kemampuan guru dalam menyusun RPP, sehingga 100\% guru MIN Amkoteng (10 orang) dapat mencapai rentang nilai minimal 76 - 90 dan atau rentang nilai 91 - 100 pada pembuatan RPP.

Data yang diperoleh dan telah diuraikan di atas dapat dibuat secara singkat dapat dilihat pada tabel berikut : 


\begin{tabular}{|c|c|c|c|c|c|c|}
\hline \multirow{2}{*}{ No. } & \multirow{2}{*}{$\begin{array}{c}\text { Rentang } \\
\text { Nilai }\end{array}$} & \multicolumn{4}{|c|}{ Hasil Penilaian RPP } & \multirow{2}{*}{ Kriteria } \\
\cline { 3 - 6 } & & Siklus I & \multicolumn{2}{c|}{ Siklus II } & Keberhasilan \\
\cline { 3 - 6 } & & Frekuensi & \% & Frekuensi & \% & \\
\hline 1. & $91-100$ & - & - & 4 & 40 & A \\
2. & $76-90$ & 8 & 80 & 6 & 60 & B \\
3. & $55-75$ & 2 & 20 & - & - & C \\
4. & $0-54$ & - & - & - & - & D \\
\hline \multicolumn{2}{|r|}{ Jumlah } & 10 & 100 & 10 & 100 & \\
\hline
\end{tabular}

Data pada tabel 3 di atas menunjukkan peningkatan dalam persentase jumlah guru yang berhasil mencapai kriteria keberhasilan penyusunan RPP. Pada siklus I hanya $80 \%$ guru yang mampu mencapai rentang nilai 76 - 91 atau dengan huruf mendapat nilai $\mathrm{B}$, sedangkan pada siklus II, $100 \%$ guru telah berhasil mencapai kriteria keberhasilan penyusunan RPP, bahkan 40\% diantaranya berhasil mencapai rentang nilai 91 - 100, atau dengan huruf mendapat nilai A.

Data pada tabel tersebut dapat tergambar dengan jelas pada grafik berikut :

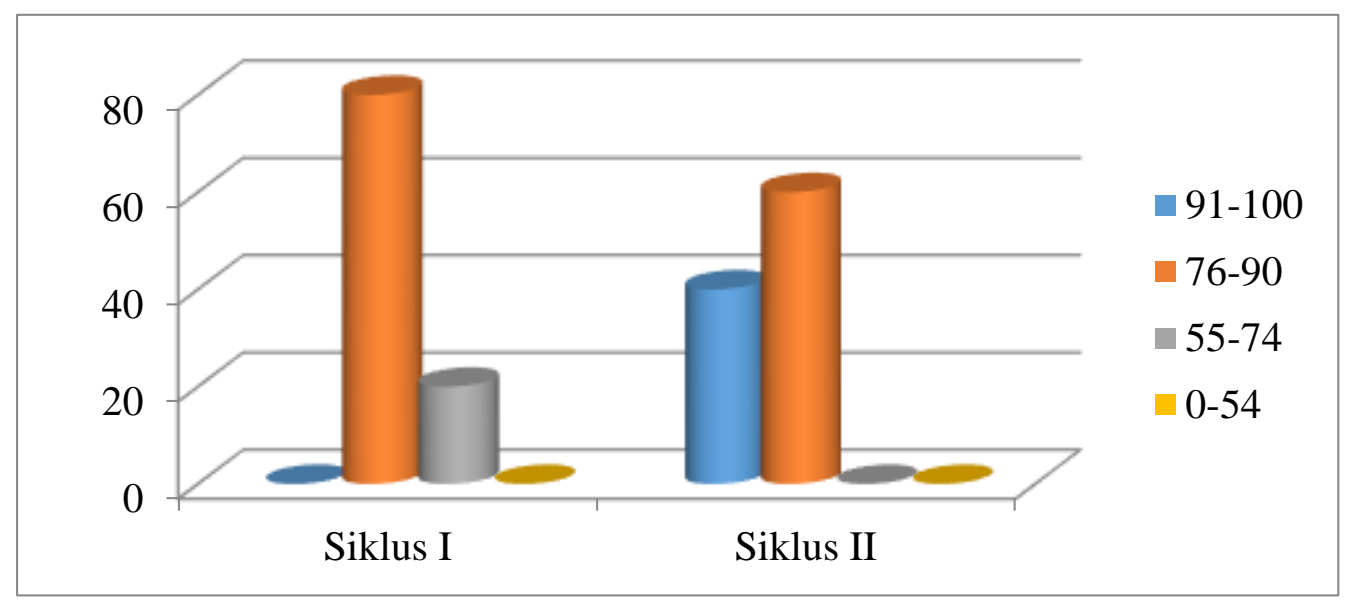

\section{Gambar 4. Peningkatan Persentase Pencapaian Rentang Nilai Keberhasilan Guru dalam Penyusunan RPP dari Siklus I hingga Siklus II}

Grafik di atas menggambarkan dengan jelas peningkatan yang terjadi dari siklus I ke siklus II. Dari data tersebut dapat dinyatakan bahwa hipotesis penelitian ini yang menyatakan bahwa "supervisi akademik dapat meningkatkan kemampuan guru dalam menyusun Rencana Pelaksanaan Pembelajaran (RPP)" dapat diterima.

\section{PENUTUP}

Berdasarkan paparan data dan pembahasan, dapat diambil kesimpulan sebagai berikut :

1. Kemampuan guru dalam menyusun RPP dapat ditingkatkan dengan supervisi akademik.

2. Kerjasama antara guru dan Pengawas Sekolah Dasar dapat terjalin dengan baik dan bermanfaat dalam membina guru untuk meningkatkan kemampuannya dalam penyusunan RPP.

3. Kelengkapan dokumen II Kurikulum Tingkat Satuan Pendidikan (KTSP) MIN Amkoteng bertambah lengkap, yaitu berupa dokumen kumpulan RPP.

4. Supervisi akademik ini dapat dijadikan model pada tahun-tahun berikutnya dalam hal penyusunan RPP, dan dapat dijadikan contoh bagi sekolah lain.

\section{DAFTAR PUSTAKA}


Aqib, Zainal. 2009. Penelitian Tindakan Sekolah untuk Pengawas Sekolah, Pengawas Sekolah Dasar dan Guru, Bandung: Yrama Widya.

Depdiknas. 2007a. Materi Sosialisasi dan Pelatihan Kurikulum Tingkat Satuan Pendidikan (KTSP), Jakarta: Direktorat Jenderal Pendidikan Dasar dan Menengah.

Depdiknas. 2007b. Pengembangan RPP - Peraturan Pemerintah No. 19 tahun 2005 dalam Sosialisasi KTSP Presentasi Power Point. Jakarta: Direktorat Jenderal Pendidikan Dasar dan Menengah.

Kemdiknas. 2010a. Penelitian Tindakan Sekolah - Materi Pelatihan Penguatan Kemampuan Kepala Sekolah. Jakarta: Direktorat Tenaga Kependidikan (Dirjen PPMPTK).

Kemdiknas. 2010b. Supervisi Akademik - Materi Pelatihan Penguatan Kemampuan Kepala Sekolah. Jakarta: Direktorat Tenaga Kependidikan (Dirjen PMPTK).

Rif'an, Ali. 2009. Implementasi Supervisi Akademik dalam Proses Pembelajaran (Antara Konsep dan Praktik). Dipublikasikan di http:// rifqiemaulana.wordpress.com / 2009 / 12 / 01 / implementasi-supervisi-akademik/, (diunduh tanggal 14 Oktober 2010). 
AL-ADZKA, Jurnal Ilmiah Pendidikan Guru Madrasah Ibtidaiyah

Volume VIII, Nomor 01, Hal (77-83)

Juni 2018 